\title{
An Investigation of Cross-Cultural Differences as They Affect Negotiations in the United States, Poland, and Russia: A Practical Guide for Negotiators
}

\author{
Barry Goldman ${ }^{1 *}$, Victoria A. D'Amato² \\ ${ }^{1}$ Department of Management and Organizations, University of Arizona, Tucson, USA \\ ${ }^{2}$ James E. Rogers College of Law, University of Arizona, Tucson, USA \\ Email: `bgoldman@eller.arizona.edu,victoriadamato@email.arizona.edu
}

How to cite this paper: Goldman, B., \& D'Amato, V. A. (2021). An Investigation of Cross-Cultural Differences as They Affect Negotiations in the United States, Poland, and Russia: A Practical Guide for Negotiators. Beijing Law Review, 12, 1016-1047. https://doi.org/10.4236/blr.2021.123052

Received: July 7, 2021

Accepted: September 27, 2021

Published: September 30, 2021

Copyright ( 2021 by author(s) and Scientific Research Publishing Inc. This work is licensed under the Creative Commons Attribution International License (CC BY 4.0).

http://creativecommons.org/licenses/by/4.0/

\begin{abstract}
In this paper, we interpret leading research on cross-cultural negotiations to provide practical guidance to practitioners either from or negotiating with, individuals from the U.S., Poland, and Russia. These countries can be considered as sharing a continuum of Western values, with the U.S. at one end, Russia at the other end, and Poland sharing some cultural values from each of the other two plus its own unique cultural values. Culturally, Poland is more similar to Russia; however, attitudinally, it shares many similarities to the U.S. We reviewed the literature in the area including papers in Polish and Russian journals. We discuss each of the cultural similarities and differences among each of these countries in the pages that follow.
\end{abstract}

\section{Keywords}

Negotiations, Poland, Russia, Cultural Differences

\section{Introduction}

Knowledge of cross-cultural negotiations is increasingly important in a globalized trade environment, such as the present one. "Culture" is the unique character of a group (Lytle, Brett, Barsness, Tinsley, \& Janssens, 1995). These are expressed in the beliefs, attitudes, norms, and behaviors of groups, as well as in their view of social, economic, political, legal, and religious institutions (Brett, 2014). Recognizing and anticipating these cultural differences can mean the difference between successful and unsuccessful negotiations. Culture affects think- 
ing, values, and the behavior of individuals, and within the last 25 years, many studies have explored the impact of interactions between individuals from different cultures on business (Rozkwitalska, Sulkowski, \& Magala, 2017). Researchers are interested in how cultures affect different forms of organizational behavior, and how people from different countries interact with each other (Rozkwitalska et al., 2017; Hofstede, 1980a; Trompenaars \& Hampden-Turner, 1997).

One area of cross-cultural differences in negotiation that has received very little attention is bundles of broad-based regional differences among negotiators within a geographic area. This information can be useful to negotiators who negotiate with organizations. The academic literature has examined cross-cultural differences among members of various countries, but tends to do this while focusing on a very narrow issue (for example, trustworthiness between Japanese and US business persons, Nishishiba \& Ritchie, 2000). The area of examination that could benefit practitioners is a broad-based comparison of cultural differences among the U.S., Poland, and Russia as they affect negotiators. These countries can be considered as sharing a continuum of Western values, with the U.S at one end, Russia at the other end, and Poland sharing some cultural values from each of the other two plus its own unique cultural values. Culturally, Poland is much more similar to Russia; however, attitudinally, it shares many similarities to the U.S. In this article, we integrate cutting-edge research to provide practical guidance to practitioners as they engage in actual negotiations with members of one or more of these three countries. We discuss each of the cultural similarities and differences among each of these countries in the pages that follow.

\section{Cultural Differences Based on Hofstede}

Geert Hofstede was a prominent social psychologist, IBM employee, and consultant who did a series of pioneering studies that established major cultural differences between countries based on several cultural dimensions including: 1) Power Distance, 2) Individualism/Collectivism, 3) Uncertainty Avoidance, and 4) Masculinity/Femininity, in which "[e]ach country has been positioned relative to other countries through a score on each dimension" (Hofstede, 2011: p. 8). We explain these cultural dimensions below and as shown is Table 1.

\section{Power Distance}

Power Distance, the first of Hofstede's dimensions of culture, is defined as the degree to which the "less powerful" members of society and organizations within a country "expect and accept that power is distributed unequally" (Balykina, 2015: p. 4; Hofstede, 2000: p. 81), acknowledging that although all societies are unequal in power distance, "some are more unequal than others" (Hofstede, 2011: p. 9). Often a nations' preference for hierarchy is caused by the state lacking fundamental democratic values, where hierarchy serves as a stabilizing factor in the unsettled social system (Rozkwitalska et al., 2017). In such nations, people accept what they are told; for example, in workplaces, subordinates are expected 
to follow the requests of their bosses without questioning them (Krzywda, 2017). The power distance scale constructed by Hofstede extends from 0 to 100 (with 0 representing the smallest discrepancies between the more and less powerful members in society, and 100 representing the largest discrepancies between the more and less powerful) (Hofstede, 2011).

Russia, scoring 93 on Power Distance, experiences big discrepancies between the more and less powerful people in society (Hofstede, 2011) with Russian business largely "characterized by a hierarchy based on power separation" (Panarina, 2020: p. 7). In Russian society, the individuals that hold power are usually distant from the less powerful (Hofstede, 2011). Successful business interactions in Russia are top-down, in which clear instructions are provided for any task requested (Hofstede, 2011). Poland, with a score of 68, is also a hierarchical society (although, less than Russia) where employees expect their bosses to explicitly tell them what to do (Hofstede, 2011). Poles largely accept the hierarchical order, with each individual clearly knowing their place (Krzywda, 2017).

By comparison, the U.S., with a score of 40 , is not a hierarchical society (Hofstede, 2011). In some places in the U.S., however, a hierarchy may be implemented for pure convenience; for example, hiring and promoting in business is often related more with prior success than seniority (Hofstede, 2011). In the U.S. business world, the low power distance orientation is visible through participative leadership, where workers have a role in decision-making in a company (Kooyers, 2015; Dorfman, Howell, Hibino, Lee, Tate, \& Bautista, 1997), and the society at large is more concerned with equality (Hofstede, 2011). In contrast with Russia, individuals in the U.S., have more to say within their organization (Rose, Carausu, Crone, \& Sengupta, 2014), and employees often have the freedom to choose the methods needed to achieve their goals (Kooyers, 2015; Dorfman et al., 1997). Moreover, in the U.S., horizontal communication is preferable in the organizations (Kooyers, 2015), instead of the top-down approach implemented in Russia or Poland. The U.S negotiators should be aware that societies scoring low on Power Distance would not be afraid to take some risk, whereas negotiators from countries scoring high on Power Distance will seek their boss' approval before making decisions (Baranowski, 2016).

Individualism/Collectivism

Hofstede's second dimension of culture, Individualism/Collectivism, is concerned with the degree that people in society are integrated into groups (Hofstede, 2011), and how strong the bonds between people in society are (Krzywda, 2017). Nations scoring high on Individualism mostly look out for themselves and their immediate family members, whereas collectivist nations, with low scores on Individualism, form into strong groups to bond and to protect all family members, including the extended family, including grandparents, uncles, and cousins (Hofstede, 2011). Thus, collectivistic nations have stronger bonds between their members, and individuals are expected to conform to the group, and to give up 
on their personal goals for the group's greater interest (Matsumoto et al., 2008). The Individualism/Collectivism scale constructed by Hofstede extends from 0 to 100 (with 0 being the most collectivist, and 100 the most individualistic) (Hofstede, 2011).

At a score of 39, Russia is a collectivistic society (Hofstede, 2011). The tradition of collectivism started in Russia early in history with the formation of the first tribal Slavic societies, continued through Orthodox Christianity and later with socialism (Panarina, 2020; Hofstede, 1980b). Russia's weak score on Individualism manifests itself in the manner Russians speak; for example, Russians implement a "we consciousness" and would say, "we go" instead of saying "my friends and I go" (Hofstede, 2011). Relationships and friends are valued more by Russians than tasks; thus, creating an authentic and trustful relationship early on is essential for obtaining information from Russians (Hofstede, 2011).

In contrast, both Poland and the U.S., scoring 60 and 91 respectively, are individualistic societies (Hofstede, 2011), although there are significant differences between the two countries on this dimension. High Individualism translates to "I" consciousness society (Hofstede, 2011), in which people prefer a loosely-knit social framework and take care only of themselves and their immediate family, without relying too heavily on the support from the government (Hofstede, 2011: p. 83). The U.S. negotiators should acknowledge the underlying norms in collectivist countries, and understand that the interest in these societies shifts from individual rights to the well-being of the negotiating partners' community (Blankley, 2013). Thus, the U.S. negotiators must be prepared to answer a question regarding how the potential outcome of the negotiation may affect the foreign negotiator's community or their family (Blankley, 2013). There is a certain contradiction in the characteristics of Polish culture, in that although Poland is an individualistic society, it relies on hierarchical order (Hofstede, 2011). These two contradictory factors combined with Poland's strong score on Power Distance makes the relationship with Poles particularly intense and delicate (Hofstede, 2011). For example, business partners in Poland obtain information through relationships and personal contacts, but some people may receive better treatment depending on their membership in a preferred group (Krzywda, 2017). Managers should improve communication by implementing personal contact with employees in the company by giving the impression that even though employees' statuses are unequal, everyone is important (Hofstede, 2011). To be more successful in negotiation, negotiators from individualistic countries such as the U.S. and Poland must be mindful that collectivist countries emphasize high context communication such as reading between lines, rather than low context (i.e., direct) communication that is explicit (Baranowski, 2016). Further, the negotiators may use to their advantage the fact that in collectivist countries such as Russia, relationships are more important than tasks, and consensus and harmony are highly valued (Baranowski, 2016).

Uncertainty Avoidance 
The third dimension of culture identified by Hofstede is Uncertainty Avoidance, which deals with a society's tolerance toward ambiguity and response to unstructured situations (Hofstede, 2011). For example, in societies with a high score of Uncertainty Avoidance, people tend to be more emotional and nervous in uncertain and ambiguous situations, whereas in counties scoring low on Uncertainty Avoidance, people tend to be more contemplative and calm (Hofstede, 2011). The Uncertainty Avoidance scale, constructed by Hofstede extends from 0 to 100 (with 0 the weakest uncertainty avoidance, and 100 the strongest uncertainty avoidance) (Hofstede, 2011). Both Poland and Russia, scoring a high 93 and 95 respectively on Uncertainty Avoidance, are nations where individuals feel threatened by ambiguous situations, and prefer to avoid uncertainty (Hofstede, 2011). Security is important in these societies, time is money, people work hard, and there is a need for rules (Hofstede, 2011). Scoring high on Uncertainty Avoidance contributes to the fact that Russians are distant and formal when interacting with foreigners (Hofstede, 2011). The combination of high Uncertainty Avoidance with high Power Distance for Russians translates into a situation where people obey rules only when they are controlled (Balykina, 2015). For example, in the Soviet era, breaking rules was a matter of survival (Rozkwitalska et al., 2017), and even now Russians may bypass procedures if they know they will not be checked (Balykina, 2015).

By comparison, the U.S., with a low score of 46 on Uncertainty Avoidance, is a society that does not need a lot of rules and is less emotionally expressive than nations with higher scores (Hofstede, 2011). Individuals from the U.S. easily accept new ideas and are willing to try new things (Hofstede, 2011). Further, Americans are more tolerant of different points of view, enjoy freedom of expression (Hofstede, 2011), and are not afraid to take risks (Rose et al., 2014). Individuals from nations scoring high on Uncertainty Avoidance can be viewed as aggressive, emotional, and busy, whereas individuals from nations scoring low on Uncertainty Avoidance can be viewed as lazy, quiet, or controlled, and negotiators should prepare to avoid forming false impressions (Baranowski, 2016).

\section{Masculinity/Femininity}

The fourth dimension of culture identified by Hofstede is Masculinity/Femininity (Hofstede, 2011). Masculinity and Femininity are concerned with the "distribution of values between the genders" in particular societies (Hofstede, 2011: p. 12 ). In general, society is masculine when people tend to be assertive or competitive, whereas it is feminine when the dominant values in society are concerned with quality of life and taking care of others without standing out of the crowd (Hofstede, 2011). The Masculinity/Femininity scale, constructed by Hofstede extends from 0 to 100 (with 0 the most feminine, and 100 the most masculine) (Hofstede, 2011). Both Poland and the U.S., with scores of 64 and 62 respectively, are relatively masculine societies (Hofstede, 2011). In masculine societies, people are expected to be assertive, and it is desirable to work to generate higher 
income and achieve the ultimate goal of obtaining a higher social status (Hofstede, 2011). In the U.S., it is important to be successful and even more important to be able to show off, thus many white-collar workers tend to move to better neighborhoods soon after promotion (Hofstede, 2011). Russia, with a low score of 36, is a feminine nation (Hofstede, 2011), but Russian business is still conducted through masculine methods (Balykina, 2015). In everyday life, Russians talk modestly about their achievements, often understate their capacities, and live modest lives (Hofstede, 2011). Russian business, however, is known to be masculine (Balykina, 2015). In feminine societies, people resolve conflicts through cooperation, whereas in masculine societies, people resolve conflicts with strength (Baranowski, 2016). Russian business, on the other hand, "follows 'male' principles" and the decision-making process is based on masculine methods from the Soviet period, when "male and females role were defined by the state" (Balykina, 2015: p. 5).

Table 1. Rankings of Hofstede Scales among the U.S., Poland, and Russia (Hofstede, 2011).

\begin{tabular}{cccc}
\hline & The U.S. & Poland & Russia \\
\hline Power Distance & 40 & 68 & 93 \\
Individualism & 60 & 91 & 39 \\
Uncertainty Avoidance & 46 & 93 & 95 \\
Masculinity & 62 & 64 & 36 \\
\hline
\end{tabular}

\section{Language, Religion and History}

Nations differ based on the characteristics of language, religion, and history that lead to the perception of one's national identity (Kardas, 2011). Cross-cultural awareness is essential for successful business negotiation because different cultures generate different negotiation styles, and culturally inappropriate behavior may lead to conflicts (Rozkwitalska et al., 2017). The negotiators must be aware of cultural differences, and adapt their negotiating tactics based upon those differences, and should "not only rely on their own codes, habits, attitudes and behaviors, but also understand and experience other's codes, habits, attitudes, and behaviors" (Qu, 2015; Wilson \& Drake, 2000: pp. 5-6). For example, cultures often influence languages, and studying a language itself may be insufficient for understanding foreigners, and thus studying language is more effective when combined with studying the culture of the target language (Adachi, 2010; King, 1990: p. 19). Religious beliefs impact the behavior and decision-making of the individuals (Richardson \& Rammal, 2018), and affect conflict resolutions (Blankley, 2013). When negotiators are prepared and know how religion impacts negotiation, they gain an advantage over their negotiating partners ( $\mathrm{Tu} \& \mathrm{Chih}$, 2011). The relationships between countries may also be affected by the history between the nations (Wolski, 2016), because history forms customs and has a very strong effect on its members (Qu, 2015). 


\subsection{U.S.-Poland}

The English language is spoken by 1.5 billion in the world and is considered to be the most successful language in international communication (Crystal, 2003), and likely "the most common business language" (Qu, 2015: p. 6). English influenced the Polish language as early as 1661 (Witalisz, 2013). The Polish language is the closest related to Czech (Katz, 2007), but some words in Polish are similar to English, and their phrases follow English structure, for example, "poprawność polityczna" (political correctness) and "gorący ziemniak" (hot potato) (Witalisz, 2013: p. 333). There are also "phraseological replicas" in the Polish language such as "miec trupa w szafie" (to have a skeleton in a cupboard) or "loanblends" such as "pracoholik" (workaholic) (Witalisz, 2013: p. 332). In Poland, English does not have an important administrative status, but is viewed as an essential foreign language to master because of the needs of business and academic communities (Crystal, 2003). Non-native speakers, however, cannot always successfully convey the meaning of words into their native language, which can lead to potential misunderstandings (Adachi, 2010). It is essential for proper communication that people engaging in conversation share "common ground underlying the notion of [a] word" (Adachi, 2010: p. 24). When conversing in English with Poles, foreign negotiators should speak slowly, use simple sentences, refrain from using confusing idioms or slang, and pause frequently to allow Poles to process the words (Katz, 2007). It can be frustrating to foreigners that Poles like to speak in their native Polish, completely ignoring the fact that foreigners may not speak Polish (Rozkwitalska et al., 2017). According to U.S. managers working with Poles, by speaking Polish, Poles avoid undesirable confrontations (Rozkwitalska et al., 2017). Even though the younger generation of business people generally speak English on a conversational level, it may be beneficial to use interpreters during the negotiation process to have a conversation with older Poles (Katz, 2007). Poles should be asked, however, if they wish to have an interpreter before the business meeting takes place because hiring one without their consent may be viewed as impolite (Katz, 2007). When negotiators rely on a professional interpreter, they should ensure that the translators pay attention to subtle cultural differences, so the differences disappear in the translation process (Qu, 2015). For example, the translator should be aware that Poles often like to use expressions and understatements that are particularly difficult to translate (Rozkwitalska et al., 2017). Even though many Poles speak Russian (Katz, 2007), they dislike when foreigners address them in Russian, and in the presentence of Poles, U.S. [negotiators] should always "stay cool about liking Russians" because Poles are generally much more friendly toward other Slavs, or Hungarians (Lewis, 2006: p. 287).

Cultural differences are often connected to values of a particular religion, or "prevailing ideologies, and underlying philosophical views" (Rozkwitalska et al., 2017: p. 57). According to the 2012 General Social Surveys (GSS) comparing the U.S. with 22 European countries (GSS), the U.S. is the tenth most religious na- 
tion, while Poland is the second most religious country of the 23 (Brauer, 2018). The United States and Poland are predominantly Christian and share a similar rate of attendance of religious events (Brauer, 2018). According to 2012 General Social Surveys (GSS) data, 58\% of Americans and 59\% of Polish respondents claimed to attend religious events on a weekly basis (Brauer, 2018). Similar to Poles, the youngest generation in the U.S. is "significantly lower on several religious characteristics than older cohorts" (Brauer, 2018: p. 654). The U.S. negotiators should always try to assess what the religion of their negotiating partners is to avoid potentially offending the partner with certain gestures or symbols (Blankley, 2013). Further, it is helpful to research whether a foreign government restricts, bans, or welcomes a particular religion because the ethics of the follower of a particular religion may change depending on how the foreign government interacts with that religion (Blankley, 2013). To avoid surprise, the U.S. negotiators should never assume that all citizens of particular foreign country practice the same religion or that all people practicing a particular religion uphold the same ethical standards (Blankley, 2013). Knowledge about the religion of the negotiating partner, combined with respect for their beliefs, helps develop mutual respect and trust between parties, which potentially leads to higher chances of achieving a successful negotiation (Tu \& Chih, 2011). As illustrated above, there is not much surprise waiting for the U.S. negotiators in Poland.

When making decisions in business, not only are the obvious and objective facts considered, but so are the personal experiences and feelings of the business people (Katz, 2007). Negotiators experience not just "differences in language or dress code, but first and foremost, in the perception of the world and the definition of business goals and motivation" (Rozkwitalska et al., 2017: p. 272). History shapes the cultural perceptions of nations. For example, Poles lean toward Westerners and tend to feel superior to Eastern European negotiators (Witaszek, 2007). The United States and Poland enjoy a strong relationship and commitment to freedom since the 'American Revolution (U.S. Department of State, 2019). During the Cold War, the relation with Poland was restrained, but since 1989, after the first Polish democratic election, the United States and Poland have "enjoyed warm bilateral relations" (U.S. Department of State, 2019). For the last 25 years, the relationship between Poland and the U.S. has been close, and Poland is one of the U.S.'s strongest European partners (Mix, 2016). Their areas of cooperation include energy security, human rights, democratization, counterterrorism, economic growth, and innovation and regional cooperation (Mix, 2016). Congress has been continuing to support Poland in the international arena. For example, in 1999 the U.S. supported Poland in joining NATO, and in 2004 it supported Poland in joining the European Union (Mix, 2016). In exchange, Poland hosts U.S. troops, facilities military exercises, contributed to operations in Iraq, Afghanistan, Kosovo, and against ISIS, and Poland is considered a great ally of the United States in Central Europe (U.S. Department of 
State, 2019). Recently, in 2019, Poland became formally designated as a participant of the Visa Waiver Program (U.S. Embassy \& Consulate in Poland, 2020). The U.S. and Poland share similar interests based upon broadly shared values such as international democracy, and the connection between Poland and the U.S. is also based on cultural ties, with 9.6 million Americans having a Polish heritage (Mix, 2016). U.S. companies enjoy doing business in Poland, viewing stability as the prime reason for doing business there (Mix, 2016). Americans are often criticized by foreigners for ignoring the culture or national histories of other nations, but once the U.S. negotiators show respect and understanding of their partner's culture and history, "they enhance the probability bargaining negotiations will begin beneficially" (Craver, 2014: p. 88). Polish history includes partitions by other nations and falling into the control of the Soviet Union, resulting in the development of a "lack of trust toward oppressive states", and Poles trust only their family or close church communities (Rozkwitalska et al., 2017: p. 164). In general, nations that were invaded by major powers tend to be suspicious of "seeiming economic invaders", and U.S. business negotiators should immediately let the negotiators from such countries know that they are interested in mutually beneficial solutions (Craver, 2014: p. 88).

\subsection{U.S.-Russia}

The Russian and English languages differ substantially in grammar and script (Grosman, 2014). Russian words usually have "more syllables, more varied stress patterns, and more articulatory complex consonant segments than those in English," there are also significant differences in the vowel system, with 5 vowel phonemes in Russian and 15 vowel phonemes in English (Grosman, 2014: p. 7). Further, Russians use the Cyrillic script, and some of the difficulties in understanding the language lies in the similarity of some of the letters to English, for example, the English V is Russian B, English $\mathrm{N}$ is Russian H, and English $\mathrm{P}$ is Russian R (1894). The Russian language is fairly popular in the U.S., and Russian is one of 10 most spoken foreign languages at home (Dubinina \& Polinsky, 2013; Potowski, 2010; Kagan \& Dillon, 2010). In Russia, negotiators may encounter communication barriers because often, Russian managers do not speak good English (Panarina, 2020). Even though it is particularly difficult to learn Russian for English speakers (Dubinina \& Polinsky, 2013), attempting to speak a few words in Russian by foreigners will be greatly appreciated (Panarina, 2020). For example, greeting in a foreign language is desirable, but the U.S. negotiators that do not speak fluent foreign language should never try to negotiate deals in the language unless they are completely fluent to avoid misunderstandings (Craver, 2014). When negotiators lack fluency in the language, it could lead to unnecessary anger or frustration, and any potential language problems must be discovered before the negotiation (Brett, 2014). Similarly, when the need for an interpreter arises, the person should be completely fluent in the language (Craver, 2014). In a situation where parties look confused and have difficulties under- 
standing the language, the U.S. negotiators should patiently explain the matter in a way that is easier for their negotiating partners to understand (Craver, 2014). The U.S. negotiators are also encouraged to use visuals like graphs, pictures, and mathematics or to allow for frequent breaks to discuss in their native language what happens during the meeting (Brett, 2014). Additionally, it is beneficial to stop the meeting when needed to ask for clarification or create subgroups, where teams discuss in their native language before choosing the best speaking representative to share their ideas (Brett, 2014).

Christianity in the U.S. differs substantially from Orthodox Christianity in Russia, but the nations share a similar percentage of the overall dominant religion (Panarina, 2020). For example, according to data from 2015, 71\% of Russians identify as Eastern Orthodox, compared to $70.6 \%$ of Americans identifying as some form of Christians (Central Intelligence Agency, 2020), we provide more details about the issues below and as shown in Table 2. Russians combine spirituality and superstition, and believe that there are things beyond control that strictly depend on the power of a god; "Russian people are true Orthodox; they are considered as God's children, and they believe that there is only one God for everyone, no matter what the name may be" (Rose et al., 2014: p. 464). The Russian Orthodox Christianity offers "certainty and feminine society values," and the appreciation of strong family ties, therefore business relationships often depend on the strength of personal relationships (Panarina, 2020: p. 8). To ensure successful cross-cultural communication with Russians, the negotiators must understand that establishing a personal relationship is essential because Russians open up through socializing (Panarina, 2020). Religious beliefs and customs often impact individuals' ethics and the manner in which nations resolve conflicts (Blankley, 2013). Though the U.S. negotiators need to become familiar with the religion of their negotiating partners' country, they should not automatically assume that their partners practice this religion or they may be surprised if they find it is not the case (Blankley, 2013). Countries with different religious orientations may prioritize different values that may affect the negotiation styles of their members (Tu \& Chih, 2011).

Russia has a complex history, including a somewhat recent shift from socialism to capitalism (Panarina, 2020). Russian and U.S. diplomatic relations were established in 1803 but ceased relatively quickly in 1909 during the Bolshevik Revolution (U.S. Department of State, 2019). Tensions between the nations intensified during the Cold War (Panarina, 2020) due to ideological differences between U.S. democratic and capitalist values colliding with communism (Glazunova, 2018). After the dissolution of the Soviet Union, the U.S. supported Russian integration into European institutions (U.S. Department of State, 2019). In 2014, the United States with G-7 partners imposed sanctions on Russia for its aggressive actions on Georgia and the annexation of Crimea, pushing Russia into a deep recession (U.S. Department of State, 2019). Russia, however, is still considered a "major economic power" with $12^{\text {th }}$ Gross Domestic Product (GDP) 
worldwide, and despite the recession, Russia "remained rather stable in terms of its competitiveness" (Panarina, 2020: p. 3). Russians are proud of their heritage and appreciate when, during business conversations, subjects about Russian history or culture are being brought up by foreign negotiators (Panarina, 2020). In the negotiations, Russians tend to act like they have nothing to lose, but they like to be seen as equal to Westerners and tend to live up to contractual obligations (Meerts, 2009). Russians pay special attention to the way foreigners speak, and negotiators should attempt to speak with Russians in "a calm, moderate tone of voice" (Panarina, 2020: p. 13), even if Russian negotiators use the threat of force, try to push their partner to compromise or show agitation or even introduce inducement (Meerts, 2009).

\subsection{Poland-Russia}

Russian and Polish cultures share a similar ethnicity, language, and communist past, however, Russian culture is East oriented and heavily influenced by Orthodox Christianity, while Polish culture is under the influence of Catholicism and is culturally West-leaning (Gerstein, Slobodskaya, Zylicz, Gosztyla, \& Nakagawa, 2010).

At first glance, communication between Russian and Poles seems fairly easy, as Slavic languages are similar in basic vocabulary, phonology, morphology and syntax (Fisher, Jargova, Stenger, Avhustinova, Klakow, \& Mart, 2016). Poles and Russians, however, do not belong to the same Slavic family group: The Polish language uses the Latin script and belongs to the West Slavic language family, while Russian uses the Cyrillic script and belongs to East Slavic languages (Fisher, Jargova, Stenger, Avhustinova, Klakow, \& Mart, 2016). Further, Poland and Russian differ in how the nations view being Slavic (Lakomy, 2011; Meller, 2007). For Russians, Slavic is a political term, and being Slavic means that other Slavs accept the political dominance of Russia, whereas for Poles being Slavic means belonging to a particular ethnical group (Lakomy, 2011; Meller, 2007). According to participants in a study of L1-Based Strategies In Learning The Grammar of L2 English And L3 Russian, some, if not all, of the grammatical structures of the Russian and Polish languages are so similar that there is little to learn in that regard (with L1 being the speaker's first language, L2 second language, and L3 third spoken language) (Wach, 2016). The linguistic similarities, however, can lead to variety of mistakes or misunderstandings when learners copy Polish structures and apply them to Russian because the languages, though similar, still have significant differences, and relying on any native language may disturb the process of thinking in foreign language (Wach, 2016). Verbal and nonverbal communication may lead to difficulties in understanding even if parties think they speak the same language (Craver, 2014). When communicating in English, Poles and Russians should use clear and concise language, and refrain from using idioms or slangs to avoid misunderstandings ( $\mathrm{Qu}, 2015)$. There are non-verbal differences between the countries that negotiators should be mindful of, for example, Poles hold a closed fist and thumbs up to wish others good luck, 
touching one's nose with the index finger means that something is a lie or a joke, and keeping eye contact is a sign that someone is honest (Laroche \& Morey, 2002). In both Russia and Poland, it is impolite to talk to someone while keeping one's hands in the pockets or chewing gum during conversations, and it is better to avoid smiling to strangers; usually most people "wear sober expressions" (Laroche \& Morey, 2002: p. 87). Additionally, in Russia in is impolite to keep one's arms folded across the chest (Laroche \& Morey, 2002).

Russia and Poland do not share similar religious beliefs; Poland is predominantly Roman Catholic, whereas in Russia, Orthodox Christianity is the predominant religion (Panarina, 2020). Throughout history, Poles used religion as a source of unity and identity to protect themselves from non-Roman Catholic intruders (Lewis, 2006). Since medieval times, Poles believed that they had a mission to defend Christianity against the neighboring Russians, viewed by Poles as "barbarous hordes spilling over the Russian Steppes and attempting to subjugate Europe" (Lewis, 2006: p. 283). Eventually, Polish religious beliefs turned to strong defensive nationalism (Lewis, 2006). Under communism, states commonly targeted religion in an attempt to replace it with atheism (Panarina, 2020). Even though communist governments similarly oppressed religious beliefs in Russia and Poland, the nations responded differently (Panarina, 2020). When the Orthodox Church was subject to political power, it did not oppose it (Kosuda, 2007). In contrast, the Catholic Church in Poland was, for the most part, independent from political power and played a role though schools and theological literature in shaping Poles' cultural lives (Kosuda, 2007). There are significant differences in how the churches in Russia and Poland were educating people; where the Catholic church in Poland emphasized the didactic aspect of religion by creating schools, the Orthodox Church in Russia did not have a didactic role, and did not teach through books but rather through examples (Kosuda, 2007). Nowadays, there is more religious diversity in Russia than in Poland, and Russian religious beliefs include both Christianity and Islam, whereas the majority of Poles are religiously homogeneous (Gerstein et al., 2010). Religious beliefs may affect negotiation and be the underlying reasons for a party's interest (Blankley, 2013). The negotiators must be mindful that some of the foreign negotiators may only come to a negotiated agreement if the agreements are aligned with the negotiators' moral or religious beliefs (Blankley, 2013). These religious or moral principles may predominate the interest of the parties, for example, an owner of domesticated animals who believes that it is inherently wrong to consume meat may be not willing to sell their animals for slaughter (Blankley, 2013).

The relationship between Poland and Russia was difficult and turbulent from the beginning of the existence of the states (Kosuda, 2007) due to different strategic interests of the countries based on geographical location, cultural and economic realities, overall safety, and ethical differences (Lakomy, 2011). In the year 966 Russia was Christianized through the Byzantine Empire, while Poland underwent Western means of Christianization, and this difference in Christianiza- 
tion laid the foundation for two contrary views of the world (Kosuda, 2007). Even the aspect of political ruling was different between the nations; while in Russia violent murders of tsars were normalized, in Poland, there was no "bloody struggle" for power (Kosuda, 2007: p. 9). Both Poles and Russian also developed unique concepts of Messianism that made the cultures collide more (Kosuda, 2007). While Polish Messianism was concerned with protecting the values and norms of Western culture, Russian Messianism was based on Byzantine values and protecting Orthodox ideology (Kosuda, 2007). Further, Poland experienced 123 years of partition between the Russian Empire, Kingdom of Prussia and Habsburg Austria (Korzeniowski, 2014). Poland always fought to establish a strong central government and fought for independence throughout its history (Krzywda, 2017), and Poles, as the most Westernized of all Slavs, turned to the West for help (Lewis, 2006). Between 1947 and 1989, Poland appeared to exist as a sovereign country; in reality, it was no more than a "prolonged arm of Soviet Union” (Kosuda, 2007: p. 17). The relation between Poland and Russia became more tense post-1989 after the Polish transition to democracy (Kosuda, 2007). The relation between the nations worsened still after the Russian annexation of Crimea in 2014 (Mix, 2016), because many Poles fear that Russia is still a real danger to Poland (Kabzińska, 2011).

Currently, different perceptions of history contribute to further conflicts between the nations (Konarska, 2013). For instance, Poles view themselves as superior to Russians due to their perception of belonging to Western European culture (Konarska, 2013) while Russians only respect strong countries that fight for their interest, and do not see Poland as an equal partner (Kabzińska, 2011). At the same time, Russophobia is common in Poland and "Poles ascribe to themselves a moral, religious, and cultural superiority over their Russian counterparts" (Uscilowicz, 2008: p. 6). Nowadays, Russians accept both authoritarian and democratic values and perceive its political system neither as democratic nor as authoritarian (Hale, 2011). Consequently, Poland chose as a part of its foreign policy to align its interest with the United States and not with Russia (Kosuda, 2007). The way the countries interact with each other may translate into business negotiations. The negotiators should be mindful that Poles tend to speak softly and never appreciate when, during conversation, business partners raise their voice (Katz, 2007). Moreover, Poles are friendly only when they are treated well, but react strongly when they think they are mistreated, and this is when Poles may feel it justified to become aggressive (Lewis, 2006). Even though Russians prefer if foreigners abstain from aggressive behavior (Panarina, 2020), Russian negotiators are willing to achieve their goals by "agitation, bribery, inducements, or any other number of things" (Meerts, 2009: p. 20). Business relationships in Russia are based on personal relationships (Panarina, 2020) and it is important for the negotiators to remember that developing personal relationships between negotiators "can often achieve miracles in cases of apparent official deadlock” (Lewis, 2006). 
Table 2. Language, religion, and history in the United States, Poland and Russia.

\begin{tabular}{|c|c|c|c|}
\hline & The U.S. & Poland & Russia \\
\hline Language & $\begin{array}{l}\text { No official language } \\
\text { English } 78.2 \% \text {, Spanish } 13.4 \% \text {, Chinese 1.1\%, } \\
\text { Other } 7.3 \% \text { (Central Intelligence Agency, } \\
2020 \text { ). }\end{array}$ & $\begin{array}{l}\text { Official language: } \\
\text { Polish } 98.2 \% \text {, } \\
\text { Silesian } 1.4 \% \text {, } \\
\text { Other } 1.1 \% \text {, unspecified } 1.3 \% \\
\text { (Central Intelligence Agency, 2020). }\end{array}$ & $\begin{array}{l}\text { Official language: } \\
\text { Russian } 85.7 \% \text {, } \\
\text { Tatar } 3.2 \% \text {, } \\
\text { Chechen } 1 \% \text {, } \\
\text { Other } 10.1 \% \\
\text { (Central Intelligence Agency, 2020). }\end{array}$ \\
\hline Religion & $\begin{array}{l}\text { Christian } 70.6 \% \\
\text { (Protestant } 46.5 \% \text {, } \\
\text { Roman Catholic 20.8\%), } \\
\text { Jewish } 1.9 \% \text {, } \\
\text { Mormon } 1.6 \% \text {, other Christian } 0.9 \% \text {, } \\
\text { Muslim } 0.9 \% \text {, } \\
\text { Jehovah's Witness } 0.8 \% \text {, } \\
\text { Buddhist } 0.7 \% \text {, } \\
\text { Hindu } 0.7 \% \text {, } \\
\text { Other } 1.8 \% \text {, } \\
\text { Unaffiliated 22.8\% (Central Intelligence } \\
\text { Agency, 2020). }\end{array}$ & $\begin{array}{l}85.9 \% \text { Roman Catholic, } \\
\text { Other catholic } 3 \% \text {, } \\
\text { Orthodox } 1.3 \% \text {, Protestant } 0.4 \% \text {, } \\
\text { Other } 0.4 \% \text { (Central Intelligence } \\
\text { Agency, 2020). }\end{array}$ & $\begin{array}{l}\text { 71\% Orthodox Christians, } \\
\text { Muslim 10\%-15\%, } \\
\text { Other Christian } 2 \% \text { (Central Intelligence } \\
\text { Agency, 2020). }\end{array}$ \\
\hline
\end{tabular}

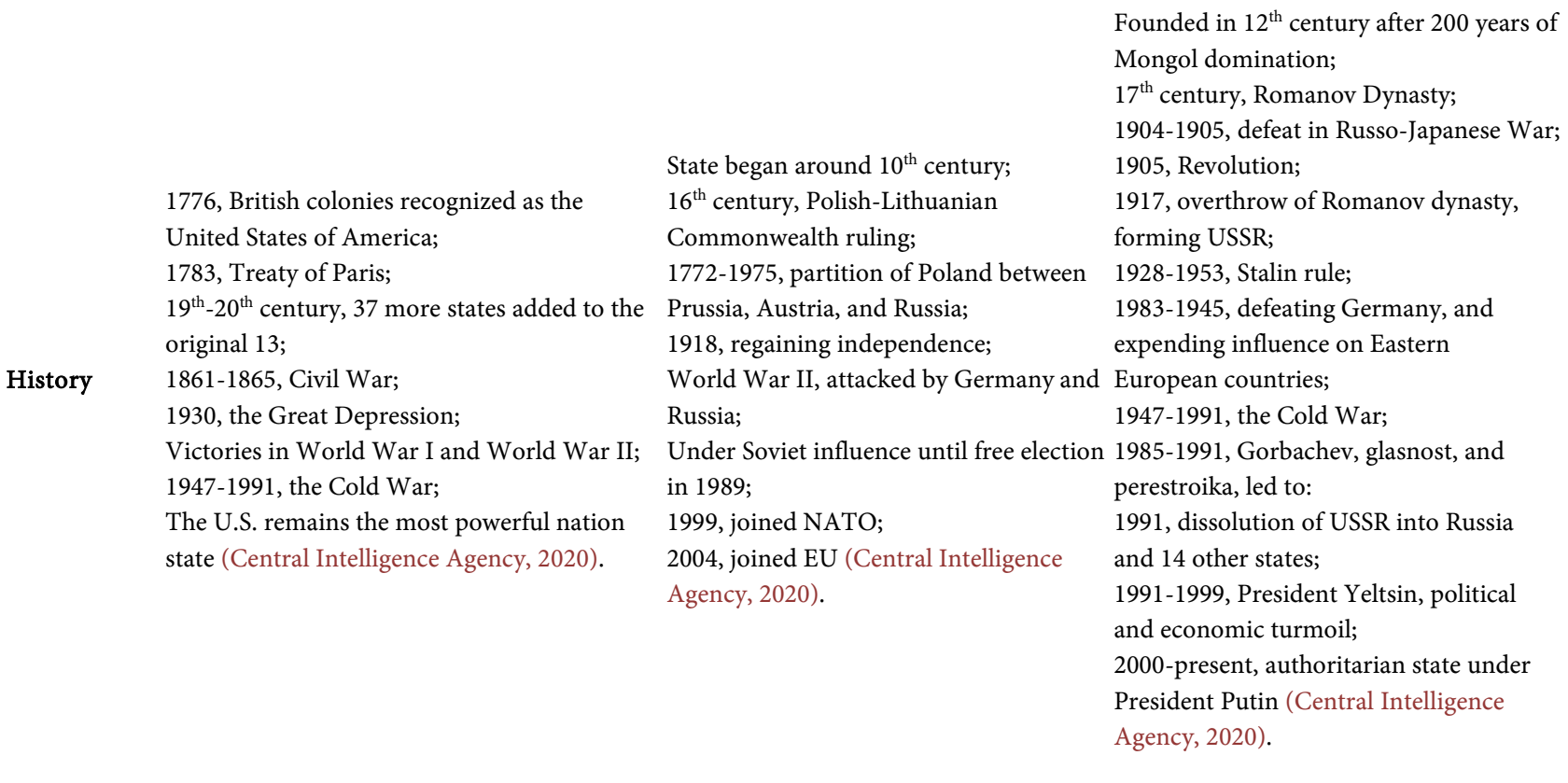

\section{Legal System, Ethics, Values, Customs, Bribery}

Different historical traditions result in "diverse legal and institutional frameworks," such as governance and educational systems (Rozkwitalska et al., 2017: p. 55), and knowing the history of the negotiating partner's country may be helpful in negotiation (Blankley, 2013). Justice may be based on agreed upon standards of behavior and sometimes based on ethics, and this is why people from different cultures have different views on what justice is (Blankley, 2013). In cross-cultural settings with different legal systems or standards, negotiators may be exposed to corruption or bribery that may test the negotiator's ethics 
(Blankley, 2013). Negotiators should understand their ethical standards to avoid surprise or "surpassing boundaries that [they] thought were inherently established" (Blankley, 2013: p. 118). The best way to prepare is to acknowledge the possibility of entering a negotiation with someone whose ethics differ, and establishing a standard-the ethical bottom line (Blankley, 2013).

\subsection{U.S.-Poland}

Poland has a civil law system with judicial review of legislative, administrative, and other governmental actions (Central Intelligence Agency, 2020). In Poland, the Constitutional Tribunal may review the Supreme Court's rulings, is independent from legislative and executive powers, and its rulings are final (Central Intelligence Agency, 2020). Countries' current and past legal systems can shape their negotiators' ethics, and in Poland, the communist regime shaped ethics with effects that are still observable (Blankley, 2013). For example, the Polish community in Chicago observed that perceptions of ethics differ between recent Polish immigrants compared to Polish-Americans citizens (Blankley, 2013). Polish-Americans, judging the ethics of new immigrants by the role of the government in Poland during communism, often believe that the recent immigrants do not want to find any work, have no work ethics, and instead rely on benefits and have an expectation that they should rightfully receive it (Blankley, 2013). In fact, Poland experienced chronic and systematic corruption and struggled to "design and implement anti-corruption strategies that can reverse or control these negative trends, in close coordination with host governments" (Lyons \& Khadiagala, 2010: p. 22). Corruption is a behavior that is not ethically, morally, or legally correct in Western countries (Brett, 2014). A major manifestation of corruption in the world's society is bribery, and it tends to appear where "the rule of law is not clearly elaborated and public officials have wide authority to act" (Mendelsohn, 2015: p. 188). In many Eastern European countries, bribery is viewed as nothing more than "tipping" or "a reward for services rendered" (Laroche \& Morey, 2002: p. 85), whereas in the U.S. it is unlawful to bribe foreign official as stated in the U.S. Foreign Corrupt Practices Act (FCPA) of 1977 (Brett, 2014), we provide more information on these topics below and as shown in Table 3. Moreover, bribery is defined in the U.S. by law in a specific manner to ensure its broad reach (Brett, 2014). For the last 20 years, fighting corruption was a priority in Poland with laws enacted to aid the cause, like the Anti-Corruption Act of 1997 (Mendelsohn, 2015), and Poland became a member of the Convention on Combating Bribery in International Business Transactions (OECD), joining 38 other countries, including the U.S. (Brett, 2014). The Polish Criminal Code provides "criminal liability both for the person accepting a bribe and for the person offering it" (Mendelsohn, 2015: p. 182). Similar to the U.S., possible criminal penalties extend to business for accepting, giving, or demanding bribes for personal benefit (Mendelsohn, 2015). In spite of all the efforts to address bribery, in 2014 only 16 people were convicted of bribery in Poland 
(Mendelsohn, 2015). Furthermore, what the U.S. negotiators may regard as bribery will be no more than a nice gift for Poles (Katz, 2007). The policies of U.S. companies have to be explained clearly to the counter partners to avoid any future ambiguities, and it is never desirable to call the local customs unethical (Katz, 2007). According to Transparency International Corruption Index, Poland ranks 41 out of 180 (its position relative to other countries), with a perceived corruption level of 58 out of 100 (100 being very clean), as compared with the United States ranking 23 out of 180 with a perceived corruption level 69 out of 100 (Transparency International, 2019).

Poland is more relationship-oriented (Rozkwitalska et al., 2017) than the U.S. Ethnic differences between populations, environmental factors, and parent-child interaction can all contribute to the development of cross-cultural differences (Gerstein et al., 2010). Americans most value independence, self-reliance and individualism (Rose et al., 2014), whereas Poles are less individualistic (Katz, 2007), more family-oriented; it is common for example for parents to kiss their children until they are adults (Lewis, 2006). Poles like to socialize and drink alcohol with people that have a strong sense of humor (Lewis, 2006); they are even perceived by other Slavs as the most unserious, of all Slavs (Wolski, 2016). It is always desirable to share a few drinks with Poles to establish relationships (Lewis, 2006) while complementing Poles on their lavish hospitability (Katz, 2007). Bringing flowers for women is also generally appreciated, unwrapping the paper around the flowers before giving it to women speaks of good manners and respect (Laroche \& Morey, 2002). Roses should be avoided because they symbolize love, as well as chrysanthemums, which are reserved for funerals (Laroche \& Morey, 2002). Flowers should not be given in an even number, as that is also reserved for funerals, and the unlucky number 13 should be avoided (Laroche \& Morey, 2002). Americans are used to carrying flowers downward, whereas Europeans always carry flowers upward, thus giving flowers facing down is generally in poor taste (Laroche \& Morey, 2002). Poles tend to have relatively large personal spaces of 40 centimeters (Wolski, 2016), and any physical contact between strangers is rare and rather unwelcome (Katz, 2007). Even though physical contact between strangers is inappropriate, it is desirable to keep frequent eye contact without staring (Katz, 2007), and it is typically in good taste to kiss women on the hand and male acquaintances on both cheeks (Lewis, 2006). It is never appropriate, however, to smile to strangers (Laroche \& Morey, 2002). The U.S. has a rather informal culture and Americans establish first-name relationship with strangers (Craver, 2014). This may, however, offend Poles that find it disrespectful unless someone is their close friend or a family member (Hall \& Hall, 1989). In most European countries, it is improper to address strangers by their first name, and the U.S. negotiators should wait until they are asked several times to address someone by their first name (Craver, 2014). In Poland, guests are always asked to come in $(\mathrm{Qu}, 2015)$, and not letting guests into the house shows bad manners and is disrespectful. This differs from the U.S., where guests 
are often left waiting in front of the door $(\mathrm{Qu}, 2015)$.

\subsection{U.S.-Russia}

Similar to Poland, Russia has a civil legal system based on legislation as the source of law (Henegan, Smith, \& Butler, 2019). Both Russia and the U.S. have a three-branch government, but in the U.S. each branch has authority that serves as a check on the other two branches (Henegan et al., 2019). By contrast, in Russia, the Constitution provides separation of power, but the president has the power to dismiss the government or dissolve the State in Duma (Konyushkevich, Rubashevskiy, \& Bazurin, 2019). Crime is of concern in Russia, and Westerners should not show off their wealth in public because they can become a target for organized crime (Laroche \& Morey, 2002). It is desirable to make a copy of passports or credit cards in case of theft (Laroche \& Morey, 2002). There is a significant difference between perceptions of corruption in the U.S. and Russia. In 1977, the U.S. enacted the Foreign Corrupt Practices Act (FCPA), which made it unlawful to bribe a foreign official, defining bribery as the intent to provide a gift in the attempt of keeping or gaining new business; a gift itself can be defined as money, or tips (Brett, 2014). In Eastern Europe, however, including Poland, bribery is pervasive (Brett, 2014) and Russian officials may expect to receive bribes (Spector, 2008). Bribes are not limited to officials and can also be offered by regular citizens to speed up administrative processes, like the process of issuing a driver's license or getting admissions to schools (Spector, 2008). Corruption usually prevails where the "rule of law is not clearly elaborated," in countries where officials are not accountable to the public, wages are not livable, the corresponding punishment is light, and public officials have broad discretion to receive benefits without the risk of being caught (Spector, 2008: p. 3). In Russia between 2007-2011, despite the efforts to combat corruption, corruption appeared to be rising (Goel \& Jo, 2012). According to Transparency International, Russia ranks 137 out of 180 (position relative to other countries) with a perceived corruption level of 28 out of 100 (low number corresponding to higher corruption), compared with the United States, which ranks 23 out of 180 with a perceived corruption level 69 out of 100 (Transparency International, 2019). Russians prefer personal rather than business-oriented favors (Lewis, 2006), and giving or receiving gifts, which is normalized in Russia, can help to develop genuine relationships with Russian partners (Panarina, 2020).

The U.S. negotiators must be approachable and understand that Russians open up slowly, and are a bit reserved at first (Panarina, 2020). It is desirable to have meals with Russian to develop a friendship (Panarina, 2020). Before having a meal with Russians, the U.S negotiators should be aware of the different drinking habits in Russia (Schweitzer \& Kerr, 2000). Even though the U.S. negotiators are usually familiar with alcohol consumption and its effect on negotiations, they need to be mindful that "the relationship between alcohol and negotiations is complicated by the fact that alcohol operates differently at different 
quantity levels and different stages of the negotiation process" (Schweitzer \& Gomberg, 2001: p. 2096). Often, business people may not recognize they are substantially under the influence of alcohol; for example, in 1979, during an arms control negotiation between the Soviet Union and the U.S., senior generals revealed secrets after drinking heavily with Soviets (Schweitzer \& Gomberg, 2001). Russians commonly use steam baths as places for a social gathering to build a more open and personal relationship with their business partners (Schweitzer \& Kerr, 2000). Alcohol tolerance increases with practice, thus negotiators that are accustomed to drink more gain an advantage when the negotiations include alcohol (Schweitzer \& Gomberg, 2001). Especially in a steam baths setting, vodka consumption is common and expected, and the U.S. negotiators should be mindful that "the combination of alcohol and dehydration from the heat can be especially debilitating" (Schweitzer \& Kerr, 2000: p. 52). The U.S. negotiators are encouraged to evaluate their alcohol tolerance before entering negotiations with partners that are regular drinkers; otherwise, they may put themselves at a disadvantage (Schweitzer \& Kerr, 2000). In Russia, alcohol is more commonly present in social settings than it is in the U.S., and Russians may initiate negotiation with drinking because it symbolizes a commitment to a successful outcome (Schweitzer \& Kerr, 2000). The U.S. negotiators may be surprised that Russians start drinking in the beginning of the negotiation rather than towards the end; it can also be a strategy in negotiation to gain an advantage over the outcome particularly because Russians have a reputation for being heavy drinkers (Schweitzer \& Gomberg, 2001). Usually, once Russians open a bottle of vodka, they will often feel they need to finish it (Schweitzer \& Kerr, 2000). In Russia, there is always a reason to drink more, and each of the toasts performed may have a different meaning: "The first toast will customarily be to the meeting, the second to the host, and additional toasts may be made to the partnership or cooperation in general" (Schweitzer \& Kerr, 2000: p. 55). Negotiators do not always consume alcohol to get an advantage over their negotiating partners; they often drink simply to relax (Schweitzer \& Kerr, 2000).

The business culture in Russia has changed since the Soviet era, and Russians now recognize cultural differences and that drinking vodka is not as common in other countries; therefore Russians may choose to go for lunch with foreigners without drinking at all (Smirnova, 2013). The U.S. negotiators should remain friendly even if Russians are hot-tempered or even when Russians threaten to end the meeting in the attempt to persuade the negotiators to their own terms (Panarina, 2020). Russian employees respect hierarchy, such as "age, rank, and protocol," and do not address managers in public because it would undermine their authority (Panarina, 2020: p. 1). Instead, to develop friendly relations and common ground with Russians, the U.S. negotiators should often indicate their distrust of blind authority, because when Russian like their partners, they will "conspire" with them to "beat the system" (Lewis, 2006: p. 377). People from the U.S. "excel in small talk," which may collide with Russians' preference to have 
deeper conversations; Russians are deal-oriented, and may also perceive small talks as not genuine (Lewis, 2006: p. 88).

\subsection{Poland-Russia}

Russia and Poland have a continental legal system based on civil law tradition (Konyushkevich et al., 2019). To become a member of the European Union, Poland had to adjust its regulation to effectively fight corruption (Kalikh, 2010). Despite the efforts, Poles perceive themselves as living in a highly corrupted country (Kalikh, 2010). As in Russia, corruption in Poland is a permanent element of life (Kalikh, 2010). According to a poll of the Public Opinion Research Center, $83 \%$ of Poles believe that corruption in Poland is a significant or very significant issue (Kalikh, 2010). Russia and Poland experience similar issues with corruption and bribery based on the similar post-Soviet economic backgrounds (Kalikh, 2010). While Poland is more successfully tackling corruption than is Russia, corruption in Russia in recent years grew and the issue became a 'systematic' problem partially because Russian legislation for a long time did not even provide a definition of corruption (Kalikh, 2010). In Russia, corruption is normalized, and according to polls, one out of three Russians consider bribery as a solution to best achieve a positive outcome for their issue (Kalikh, 2010). Similarly, many Poles do not view minor monetary compensation as bribery, and rather as something that helps them "getting a job done" (Katz, 2007: p. 4).

The tradition of drinking vodka is similar in Poland and Russia. Poland and Russia have been producing vodka since the 16th century (Wolska, 2001). Poles and Russian consume alcohol during business meetings to establish a relationship, and it is a signal for one another that they want to do business together (Katz, 2007). In both Russian and Polish cultures, drinking is "equated with openness and candor," and if someone refrains from drinking, the person appears suspicious and not to be trusted (Schweitzer \& Kerr, 2000: p. 53). Bringing a bottle of vodka and wrapped chocolate as a gift is appreciated by both men and women (Laroche \& Morey, 2002). Both Poles and Russians prefer to have longer, more meaningful conversations rather than small talk, of which they are not fond (Lewis, 2006). Sitting down by Poles or Russians, talking, and drinking helps to establish trust, and ensure positive outcomes of potential negotiations (Lewis, 2006).

While Poles value family, health, honesty, quiet life, career, faith, friendships and respect of others (Public Opinion Research Center, 2010), Russians most value respect for the elderly, family, patriotism, and carrying for children until they become independent (Panarina, 2020). The core values of Russian culture consist of friendship, spirituality, creativity, perseverance, but also fatalism (Panarina, 2020). The relationships between people are essential for Russians because "the interests of the community are above personal interests, and therefore personal plans, purposes, and interests are so easily suppressed" (Rose et al., 2014: p. 464). Russian like to keep a personal space of 20 - 30 centimeters, which is nearly half of the Poles' personal space (Wolski, 2016). 
Table 3. Legal systems, bribery and ethics in the United States, Poland, and Russia.

\begin{tabular}{|c|c|c|c|}
\hline & U.S. & Poland & Russia \\
\hline Legal system & $\begin{array}{l}\text { Common law federal and state (except } \\
\text { Louisiana) }\end{array}$ & Civil law system & Civil law system \\
\hline Bribery & $\begin{array}{l}\text { 1977, Foreign Practices Act (FCPA), made } \\
\text { unlawful to bribe officials by U.S. citizens, and } \\
\text { certain foreigners (Brett, 2014). } \\
\text { United States V. Hoskins, } 902 \text { F.3d. } 69 \text { (2d Cir. } \\
\text { 2018), the Court held that a foreigner that had } \\
\text { never visited the U.S. cannot be liable for } \\
\text { violating FCPA due to territorial limitations. }\end{array}$ & $\begin{array}{l}\text { For the last } 20 \text { years fighting corruption was } \\
\text { a priority in Poland. } \\
\text { 1977, Anti-corruption Act of 1997, passed to } \\
\text { aid corruption (Mendelsohn, 2015). } \\
\text { Polish Criminal Code provides "criminal } \\
\text { liability both for the person accepting a } \\
\text { bribe and for the person offering it" } \\
\text { (Mendelsohn, 2015). } \\
\text { Possible criminal penalties extend to } \\
\text { business for accepting, giving or demanding } \\
\text { bribes for personal benefit (Mendelsohn, } \\
\text { 2015). }\end{array}$ & $\begin{array}{l}\text { Bribes demanded by officials more } \\
\text { frequently than being offered by } \\
\text { citizens (Spector, 2008). } \\
\text { In Russia, despite the efforts to fight } \\
\text { corruption the situation recently } \\
\text { worsened (Goel \& Jo, 2012). }\end{array}$ \\
\hline Ethics/values & $\begin{array}{l}\text { (1) Egalitarianism and equality, } \\
\text { (2) Privacy and independence, } \\
\text { (3) Competition and free-enterprise, } \\
\text { (4) Honesty, openness and directness, } \\
\text { (5) Informality, } \\
\text { (6) Individualism, } \\
\text { (7) Personal control over the environment, } \\
\text { (8) Change and mobility, } \\
\text { (9) Materialism, } \\
\text { (10) Practicality, } \\
\text { (11) Action and work orientation, } \\
\text { (12) Future orientation, } \\
\text { (13) Time control (Kohls, 1988). }\end{array}$ & $\begin{array}{l}\text { Poles value the most family and health. } \\
\text { Poles also value respect from others faith, } \\
\text { career, and quiet life } \\
\text { (Public Opinion Research Center, 2010). }\end{array}$ & $\begin{array}{l}\text { The } 5 \text { most important values in } \\
\text { Russian culture are: } \\
\text { (1) Friendship } \\
\text { (2)Warm-heartedness valuing deeper } \\
\text { emotions over materialism } \\
\text { (3) Innovation in problem solving } \\
\text { (4)Fatalism, believing that individuals } \\
\text { have little control over their lives } \\
\text { (5) Persistence (Panarina, 2020). } \\
\text { Russians also value family life; having } \\
\text { children, respect for the elderly; } \\
\text { Patriotism, and sense of humor } \\
\text { (Panarina, 2020). }\end{array}$ \\
\hline
\end{tabular}

\section{Trust Perceptions}

Poles and Russians are generally distrustful of foreigners and "want to do business only with those they like and trust" (Katz, 2007: p. 1). The distrust affects perceptions and the manner in which they view each other. In the 20th century, Poles believed that a true patriot should never attempt to make any agreements with Russians because Russians' motivations are always concerned with stripping Poland of its independence (Konarska, 2013). Russians were and are perceived as liars, occupants (Mazurkiewicz, 2015), and wild, barbaric, cruel drunkards (Konarska, 2013), we provide more details about the issues below and as shown in Table 4. Russians, on the other hand, view Poland as an unhappy, arrogant nation with a false perception of superiority (Konarska, 2013). The perceptions of both nations are rooted in history, when Poles often conspired against Russians, had never felt defeated by them, and dreamt of rebuilding Poland (Konarska, 2013). Russians do not appreciate that Poles cannot be happy with what they have and view Poles as a nation of dissatisfied people that always 
demanding something better (Konarska, 2013). According to 2014 research conducted by the Polish-Russian Center for Dialog and Communication, $82 \%$ of Polish participants viewed Russia's relation toward Poland as either unfriendly or very unfriendly, while $85 \%$ of Poles viewed the U.S. politics toward Poland as friendly or very friendly (Mazurkiewicz, 2015). Further, 75\% of Polish respondents viewed Russia as undemocratic, and 75\% perceived Russia as untrustworthy (Mazurkiewicz, 2015). At the same time, 66\% of Russian respondents viewed Poland as unfriendly toward the Russian Federation as compared to $89 \%$ who viewed the U.S. as unfriendly toward the Russian Federation (Mazurkiewicz, 2015). Russians rate the unfriendliness of U.S. citizens and Poles at $58 \%$ and $43 \%$ respectively (Mazurkiewicz, 2015). Moreover, 14\% of Polish respondents believed that the U.S. is the most fitting nation with which to have an honest conversation, whereas 27\% view Russia as least fitting (Mazurkiewicz, 2015).

Poles endured two world wars, the partitioning of Poland, and communist regime, and during that time Poland did not have the "proper conditions to develop international trade and that is why does not have a strong tradition in negotiation," and this is why Poles are distrustful of non-Polish negotiation partners (Chmielecki \& Sulkowski, 2014: p. 54). Additionally, the distrust is based on the early history of Poland, when the nation was occupied and seized by many powers (Katz, 2007). Poles living in the Eastern part of Poland were influenced by the values of the Russian Empire, and tend to be more distrusting than Poles from the Western part, who are also "better predisposed to democracy than inhabitants of former Russian and Recovered Territories” (Korzeniowski, 2014: p. 51). In studies conducted in 2014, $74 \%$ of Polish respondents believed people have to be careful in trusting others, whereas only $23 \%$ of respondents believed they could trust people (Chmielecki \& Sulkowski, 2014). U.S. citizens, on the other hand, are more likely to trust foreigners (Gunia \& Brett, 2011). The U.S. negotiators need to be patient, as Poles are suspicious (Baranowski, 2016), and the process of developing trust and friendship by Poles may include many personal questions (Katz, 2007). Even though Poles seek personal contact with their negotiating partners, they will maintain a distance with people they do not know (Baranowski, 2016). Poles often listen to official directives with distrust and skepticism in an attempt "to detect minor slights" (Lewis, 2006: p. 286), and newly developed trust is not always automatically granted and has to be renewed each meeting (Baranowski, 2016). It is not desirable to bring a lawyer to a negotiation with Poles because it shows distrust (Katz, 2007). In the U.S., during business negotiation, the negotiators will usually stand two feet apart (Craver, 2014), while Poles prefer to stand three feet apart from a stranger and engage in indirect, quiet conversation (Katz, 2007). When Poles think they can trust their partners, they are not as guarded, and show emotions openly "to the point of bluntness" (Katz, 2007: p. 2).

Russia, unlike the U.S., is a high-context culture with a low trust environment (Louneva, 2010). A high context culture refers to nations that share a long history of deeper connections, so "indirect communications are understood based 
on a deeper level of understanding," while low-context nations share few connections, and because of that, "behaviors and communications need to be more direct and explicit" (Louneva, 2010: p. 4). At first, Russians tend to be suspicious and distrustful of foreigners and it takes time to build a trusting and open relationship (Balykina, 2015). To establish trust with Russians, the U.S. negotiators must form personal relationships, prioritize the relationship, remain patient, and focus "on top-down decision making" (Louneva, 2010: p. 7). Forming personal relationships with Russians is the most important aspect of a potentially successful negotiation, and it is recommended that such a relationship should be developed in a less formal setting than a typical conference room, preferably in a local restaurant where negotiators can sit down and share a meal (Louneva, 2010). The U.S. negotiators must expect to engage in a different process of negotiation than in the U.S., and instead of starting the negotiation by discussing the details with the goal of ending up with a final agreement, they should first establish trust, and only then discuss the agreement, leaving the details for the end (Louneva, 2010: p. 8). Discussions with Russians are particularly difficult for a purely financially oriented negotiator because in Russia, "things are looked at an emotional level rather than what are facts, the consequences, and so on," and this is why building trust with Russians is essential (Louneva, 2010: p. 8).

Table 4. Stereotypes about trust regarding Americans, Poles, and Russians.

\begin{tabular}{|c|c|c|c|}
\hline & The U.S. & Poland & Russia \\
\hline Trust & $\begin{array}{l}\text { More likely to trust foreigners than } \\
\text { members of other two countries. }\end{array}$ & $\begin{array}{l}\text { Generally distrustful of } \\
\text { foreigners }\end{array}$ & Generally distrustful of foreigners \\
\hline \multirow[t]{12}{*}{ Stereotypes } & Views on Poles: & Views on Russians: & Views on Poles: \\
\hline & $\begin{array}{l}\text { Distrustful, and automatically assumes } \\
\text { unethical behavior, }\end{array}$ & $\begin{array}{l}\text { Liars and occupants } \\
\text { (Mazurkiewicz, 2015), }\end{array}$ & Very unfriendly (Mazurkiewcz, 2015). \\
\hline & $\begin{array}{l}\text { Personal relations lead to commitment } \\
\text { in professional life, }\end{array}$ & $\begin{array}{l}\text { Wild, barbaric, and cruel } \\
\text { drunkards (Konarska, 2013). }\end{array}$ & $\begin{array}{l}\text { Unhappy, arrogant nation with a false perception of its } \\
\text { superiority (Konarska, 2013). }\end{array}$ \\
\hline & & & Russian view on the people from the U.S.: \\
\hline & $\begin{array}{l}\text { Poles are hard to understand } \\
\text { (Rozkwitalska et al., 2017). }\end{array}$ & Views on people from the U.S.: & Very unfriendly, \\
\hline & Views on Russians: & $\begin{array}{l}\text { Trustworthy and honest } \\
\text { (Mazurkiewcz, 2015). }\end{array}$ & $\begin{array}{l}\text { The U.S. viewed as the most culturally incompatible with } \\
\text { Russia, even more incompatible than China. }\end{array}$ \\
\hline & The Russian "peasant-commune", & & \\
\hline & “Thinking alike and acting alike", & & $\begin{array}{l}\text { The U.S. viewed as one of the most pathological countries } \\
\text { known for drugs, corruption and alcohol (MazurkiewcZ, } \\
\text { 2015). }\end{array}$ \\
\hline & Impulsive and emotional, & & \\
\hline & Depend on authority, & & \\
\hline & $\begin{array}{l}\text { Russian as a worker as elf-interested } \\
\text { "brute", }\end{array}$ & & \\
\hline & Uncivilized (Tomi, 2001). & & \\
\hline
\end{tabular}




\section{Gender Differences}

Gender differences in negotiation are often based on social norms; for example, women tend to perform as well as men if the item of negotiation is considered feminine, but worse than men if the item is masculine (Toosi, Mor, Semnani, \& Philips, 2018). In the U.S., gender differences are visible in the income differential between women and men, with women being compensated less than men, and the "\$1000 difference in starting salary [between women and men] could translate into about half a million dollars lost over the course of a career" (Toosi et al., 2018). Additionally, gender differences also vary by race, with studies suggesting that white women get $\$ 81.3$ for every dollar white men get, Asian women $\$ 74.8$, and Asian men $\$ 95.8$ (Toosi et al., 2018), we provide more information on these topics below and as shown in Table 5 .

In the $19^{\text {th }}$ and $20^{\text {th }}$ century, Polish men went to war while Polish women were left to take care of their family, and these circumstances led to the creation of the perception of the ideal woman: strictly devoted to her family, strong and selfless with no life of her own: "Matka Polka" - the Polish Mother (Wejnert \& Djumabaeva, 2005). This glorified self-sacrifice was embodied in the communist system, where Polish women were portrayed as an active work force: miners, tractor drivers, or bricklayers (Wejnert \& Djumabaeva, 2005). By the end of 1980, a more traditional model of mother-homemaker became predominant due to the influence of Catholic tradition (Wejnert \& Djumabaeva, 2005). For decades, Polish women sacrificed their careers and individual aspirations for the needs for their families; however, democracy initiated the slow process of moving the desirable social order from patriarchy to egalitarianism (Wejnert \& Djumabaeva, 2005). Even though Poland signed the Convention on the Elimination of All Forms of Discrimination Against Women ("CEDAW") in 1980, the Polish government has never "defined gender equality as a priority policy aim" (Warat, 2014: p. 6). Instead, the Polish government viewed gender equality as problematic, and supported family values or "natural/traditional gender roles" (Warat, 2014: p. 6). The gap in gender inequalities was reduced when Poland joined the European Union in 2004 (Warat, 2014). In 2014, the CEDAW Committee suggested that the Catholic Church contributes to degrading and downplaying implementing gender equality in Poland; at the same time, the Catholic Church in Poland fought back and accused the EU of threatening traditional Polish family values (Warat, 2014).

Business in Poland is not immune to gender differences, and women still struggle to obtain job positions with the same income or authority as men (Katz, 2007). Women in Poland are usually better educated than men; yet earn less within every level of education (Goraus \& Tyrowicz, 2014). Visiting foreign businesswomen are encouraged to immediately establish their authority by emphasizing their company's importance and the importance of their role (Katz, 2007). Finally, businesswomen are expected to show only a certain degree of assertiveness and confidence, but they should never appear aggressive or bold (Katz, 
2007). At the same time, "[m]ale chivalry is a sign of good manners and should be graciously accepted," and the hand-kissing of women by men should never be refused (Katz, 2007: p. 5). There is also a presumption in Poland that women should not be involved in politics because they are "emotional, have difficulties in making decisions, and [will] not be competitive or assertive (Warat, 2014: p. 68). Violence against women is a serious concern in Poland, and for decades domestic violence was treated as a private matter "which should be dealt with at the level of the family, without noticing that it affected women to a greater extent than men" (Warat, 2014: p. 106). Violence for decades was not viewed as a political issue, and the state failed to protect its female citizens (Warat, 2014). Nowadays, Poland is close to achieving a gender-equal society, with a gender income gap currently at $8 \%$ as compared to 2005 when the gap was $25 \%$ (European Institute for Gender Equality, 2017). Poland is viewed as the closest Slavic nation to Western culture, and thus, Poland has more in common with France or other Western countries than with Russia, and it is easier for Westerners to negotiate with Poles than with Russians based on their cultural similarities (Baranowski, 2016).

Russia has a highly patriarchal culture with polarized gender roles, and even business etiquette in Russia is gender oriented (Panarina, 2020). There are stereotypes about women in Russia that make women less attractive as a workforce such as that "women's labour force is less profitable and demands bigger investments than men's" (Rimashevskaya, 2013). The gender segregation is visible in a job occupation's "glass ceiling" that manifests through real and artificial barriers, "which exist in the form of prejudices and institutional bars and prevent women from getting higher managerial positions" (Rimashevskaya, 2013: p. 56). Gender differences also take a more subtle form and manifest as specific dress codes in the workplace, where Russian women are supposed to wear attractive and feminine clothing in the office and are openly complimented by male co-workers, or receive "other gestures" from males when they do (Panarina, 2020: p. 11), which could be potentially perceived as a harassment in the U.S. The gender oriented business in Russia is also visible in other situations, like where men are expected to cover a bill in a restaurant or help women carry their purses and hang coats (Panarina, 2020). Sexual harassment is more prevalent in Russia, and foreign women should be aware that if they go to hotel nightclubs and other drinking places, "plenty of men will assume [they] are prostitute[s]" (Laroche \& Morey, 2002: p. 86). The gender inequality affects family dynamics, and women may lose their jobs and become servants of their husbands (Rimashevskaya, 2013). Women initiate around 70\% of divorces in Russia, and many of the separations are caused by domestic violence (Rimashevskaya, 2013). Even though new trends and changes in recent years suggest that it is more desirable to view negotiations as a collaborative process in cross-cultural settings "aimed at finding the best solution for everyone involved," the traditional male traits of antagonism, assertiveness, and aggression usually are still the most de- 
sirable in a cross-cultural setting (Blankley, 2013: p. 78). U.S negotiators should always know their audience and know what values are preferred at the bargaining table before implementing them (Blankley, 2013).

Table 5. Differences in Gender between the United States, Poland, and Russia.

\begin{tabular}{|c|c|c|c|}
\hline & The U.S. & Poland & Russia \\
\hline \multirow[t]{8}{*}{$\begin{array}{l}\text { Gender } \\
\text { differences }\end{array}$} & Gender differences visible in the income, & $\begin{array}{l}\text { Change from patriarchy to egalitarianism } \\
\text { (Wejnert \& Djumabaeva, 2005). }\end{array}$ & Highly patriarchal culture, \\
\hline & \multirow{7}{*}{$\begin{array}{l}\text { Gender differences vary by race; studies suggest } \\
\text { that white women get } 81.3 \text { for every dollar } \\
\text { white men get, Asian women } 74.8 \text {, while Asian } \\
\text { men are paid } 95.8 \text { for every dollar a white man } \\
\text { earns (Toosi et al., 2018). }\end{array}$} & & Polarized gender roles; \\
\hline & & $\begin{array}{l}\text { Gender differences in business; women struggle to } \\
\text { obtain job positions with the same income or } \\
\text { authority as men (Katz, 2007). }\end{array}$ & $\begin{array}{l}\text { Traditionally family oriented } \\
\text { (Panarina, 2020). }\end{array}$ \\
\hline & & $\begin{array}{l}\text { Businesswomen are expected to show only a certain } \\
\text { degree of assertiveness and confidence, but they } \\
\text { should never appear aggressive or bold (Katz, 2007). }\end{array}$ & $\begin{array}{l}\text { Women are often servants to } \\
\text { husbands (Rimashevskaya, } \\
\text { 2013) }\end{array}$ \\
\hline & & $\begin{array}{l}\text { Presumption that women should not be involved in } \\
\text { politics because they are too emotional and not } \\
\text { assertive (Warat, 2014). }\end{array}$ & $\begin{array}{l}\text { Business etiquette gender } \\
\text { oriented }\end{array}$ \\
\hline & & & Dress code (Panarina, 2020). \\
\hline & & Violence against women (Warat, 2014). & \\
\hline & & $\begin{array}{l}\text { Women in Poland are usually better educated than } \\
\text { men and earn less in every education category } \\
\text { (Goraus \&Tyrowicz, 2014). }\end{array}$ & $\begin{array}{l}\text { Prevalent sexual harassment } \\
\text { (Rimashevskaya, 2013). }\end{array}$ \\
\hline
\end{tabular}

\section{Negotiations Styles: Distributive or Integrative}

Distributive bargaining is concerned with "efforts to maximize gains and minimize losses within a 'win-lose' or self-gain orientation" (Baranowski, 2016: p. 22; Putnam et al., 1990) by gaining an advantage over the negotiating party to obtain the largest proportion of available resources possible (Blankley, 2013). By contrast, integrative negotiation aims to reconcile the interests of both parties, reach joint benefits, or attain 'win-win' goals” (Baranowski, 2016; Putnam et al., 1990) by expanding the available resources (Blankley, 2013).

Russians prefer a distributive rather than integrative approach to negotiation (Roemer et al., 1999), and Russian negotiators are often viewed as inflexible, competitive, confrontational, uncompromising, and stubborn (Roemer et al., 1999). This preference is based either on organizational and bureaucratic constraints of the communist past, or alternatively on the existing ethical system in Russia (Roemer et al., 1999). According to Lefebvre (1982: p. 7), people from the U.S. and Russians have different ethical systems, where individuals from the U.S. are governed by a "first ethical system," in which individuals seek compromise to resolve disputes and prefer a problem-solving approach, whereas Russians are governed by the "second ethical system," in which individuals "try either to create new conflicts or exacerbate existing ones with adversaries" (Roemer et al., 1999: p. 46; Lefebvre, 1982). This hypothesis was presented to explain Russians' "uncompromising" attitude, and based on an empirical study Lefebvre con- 
cluded that " $[t]$ he majority of former Soviet citizens consider it acceptable to use bad means to achieve good goals ... and ... the majority of Americans disagree with this" (Roemer et al., 1999: p. 46; Lefebvre, 1982: p. 6). Although, Poles initially appear highly adversarial and competitive, they usually value long-term relationships, engage in problem-solving processes, and like U.S negotiators, are interested in win-win solutions (Katz, 2007). Poles may engage in direct and aggressive negotiating, but even then they are interested in a solution acceptable by both sides (Katz, 2007).

\section{Research Summary}

Approach to Negotiations. The primary framework we have relied on in crafting this paper is the landmark work of Hofstede $(1980 \mathrm{~b}, 2000,2011)$ to discuss cultural differences. His identification and reliance on Power Distance, Individualism/Collectivism, Uncertainty Avoidance, and Masculinity/Feminity provide a useful perspective to identify important cultural differences among how negotiators differentially approach negotiations in Russia, the United States, and Poland. For example, Russia scores highest on Power Distance, Poland is in the middle of the group, and the U.S. is third (Hofstede, 2011). Therefore, Russian negotiators are more concerned with the perceived differences in society (Hofstede, 2011). The U.S. scores highest on Individualism/Collectivism, Poland is in the middle of this group, and Russia is third (Hofstede, 2011). Therefore, the U.S. negotiators must be mindful that in collectivist countries, relationships are more important than tasks (Baranowski, 2016). Russia scores highest on Uncertainty Avoidance, Poland is in the middle of the group with a score slightly lower than Russia, and the U.S. is third (Hofstede, 2011). Therefore, Russian and Polish negotiators tend to be more emotional and nervous in uncertain and ambiguous situations, while the U.S. negotiators tend to be more calm and competitive (Hofstede, 2011). The U.S. scores highest on Masculinity and Femininity, Poland is in the middle of the group with a score slightly lower than the U.S., and Russia is third (Hofstede, 2011). Therefore, the U.S. and Polish negotiators tend to be more assertive, while Russians, although feminine as a society, follow masculine principles in business (Balykina, 2015: p. 5).

Behavioral Differences among Negotiators. These attitudinal differences express themselves differently when negotiators from the U.S., Poland, and Russia negotiate with each other.

\subsection{U.S.-Poland}

When negotiating with Poles, the U.S. negotiators should be mindful that Poles often like to use expressions and understatements that are difficult to translate (Rozkwitalska et al., 2017), possibly as an expression of in-group identification. Poles have difficulty trusting non-in-group members (i.e., close members of family or church communities, Rozkwitalska et al., 2017: p. 164), and the U.S negotiators should take care to avoid expressing affection for Russia or Russians 
(Lewis, 2006: p. 287). Where Americans value independence, self-reliance, and individualism, Poles are more family-oriented (Katz, 2007). The U.S. negotiators should be mindful that Poles like to socialize and drink alcohol, and it is always desirable to share a few drinks with Poles to establish relationships (Lewis, 2006). However, Poles have a relatively large personal space of 40 centimeters (Wolski, 2016), and physical contact between strangers is unwelcome (Katz, 2007). In the U.S., during a business negotiation, the negotiators will usually stand two feet apart (Craver, 2014), while Poles prefer to stand three feet from a stranger and engage in indirect, quiet conversation (Katz, 2007). U.S negotiators must be mindful that it is improper to address strangers by their first name (Craver, 2014). It is not desirable to bring a lawyer to negotiate with Poles because it shows distrust (Katz, 2007). When Poles think they can trust their partners, they are not as guarded, and show emotions openly "to the point of bluntness" (Katz, 2007: p. 2).

\subsection{U.S.-Russia}

U.S. negotiators must be approachable and understand that Russians open up slowly (Panarina, 2020). Forming personal relationships with Russians is the most important aspect of a potentially successful negotiation, and it is recommended that such a relationship should preferably be developed in a local restaurant where negotiators can sit down and share a meal (Louneva, 2010). Russians prefer personal rather than business-oriented favors (Lewis, 2006), and giving or receiving gifts can help to develop genuine relationships with Russian partners (Panarina, 2020). However, U.S. negotiators should be attentive to attempts by Russians to use the threat of forceful attempts to extract concessions (Meerts, 2009). Businesswomen are expected to show a certain degree of assertiveness and confidence, but should never appear aggressive or bold (Katz, 2007). It is desirable to have meals with Russians to develop a friendship (Panarina, 2020). In Russia, alcohol is more commonly present in social, as well as some business, settings than it is in the U.S., and Russians may initiate negotiations with drinking because it symbolizes a commitment to a successful outcome (Schweitzer \& Kerr, 2000). Negotiators with a high alcohol tolerance that may gain an advantage (or less of a disadvantage) with negotiations that include alcohol (Schweitzer \& Gomberg, 2001).

\subsection{Poland-Russia}

When Polish negotiators engage with Russian partners, the Poles may view themselves as superior to Russians, while Russians may likewise view themselves as superior to the Poles (Kabzińska, 2011). Poles tend to speak softly during conversations, but become aggressive when they perceive mistreatment (Lewis, 2006), while Russians negotiators are willing to achieve goals by agitation or inducement (Meerts, 2009: p. 20). In Russia, corruption is normalized (Kalikh, 2010). Similarly, many Poles do not view minor monetary compensation as bri- 
bery, and rather as something that helps them in "getting a job done" (Katz, 2007: p. 4). In both Russian and Polish cultures, drinking is "equated with openness and candor," and if someone refrains from drinking, the person appears suspicious and not to be trusted (Schweitzer \& Kerr, 2000: p. 53). The negotiators should be attentive that Russians like to keep a personal space of 20-30 centimeters, which is nearly half of the Poles' personal space (Wolski, 2016).

\section{Conclusion}

In this paper, we have presented a guide for individuals negotiating with members of the U.S., Poland, or Russia, whether those negotiators are from one of these three countries or from some other countries. We have grounded our practical guidance in research relating to cultural similarities and differences as identified by research. We believe this broad-based comparative guidance to be particularly useful to help identify cultural differences that may have not been previously overlooked.

\section{Conflicts of Interest}

The authors declare no conflicts of interest regarding the publication of this paper.

\section{References}

Adachi, Y. (2010). Business Negotiations between the Americans and the Japanese. Global Business Languages, 2, 20-30.

Balykina, G. (2015). Intercultural Aspect of Russian Business Negotiation Practices (pp. 1-8). Institute of Administration Presidential Academy of National Economy and Public Administration. https://doi.org/10.2139/ssrn.2577188

Baranowski, N. (2016). The Influence of Culture on Negotiation-Differences and Similarities in Conducting a Negotiation in France and Poland (pp. 1-111). Thesis, University of Vaasa, Department of International Studies. https://osuva.uwasa.fi/handle/10024/2806

Blankley, K., Ed. (2013). Cross Cultural Negotiation for U.S. Negotiators. https://moritzlaw.osu.edu/programs/adr/docs/cross_cultural_negotiation.pdf

Brauer, S. (2018). The Surprising Predictable Decline of Religion in the United States. Journal for the Scientific Study of Religion, 57, 654-675. https://doi.org/10.1111/jssr.12551

Brett, J. M. (2014). Negotiating Globally: How to Negotiate Deals, Resolve Disputes, and Make Decisions across Cultural Boundaries (3rd ed.). Jossey-Bass.

Central Intelligence Agency (2020). The World Factbook 2020. Washington DC.

Chmielecki, M., \& Sulkowski, L. C. (2014). The Issue of Trust in Cross-Cultural Negotiation. The Case of Poland. Journal of Intercultural Management, 12, 49-60.

Craver, B. C. (2014). How to Conduct Effective Transnational Negotiations between Nations, Nongovernmental Organizations, and Business Firms. Washington University Journal of Law \& Policy, 45, 69-103.

https://openscholarship.wustl.edu/law_journal_law_policy/vol45/iss1/9

https://doi.org/10.2139/ssrn.2670011 
Crystal, D. (2003). English as a Global Language (2nd ed., pp. 1-112). Cambridge University Press. https://www.cambridge.org/9780521823470 https://doi.org/10.1017/CBO9780511486999

Dorfman, P., Howell, J., Hibino, S., Lee, J., Tate, U., \& Bautista, A. (1997). Leadership in Western and Asian Countries: Commonalities and Differences in Effective Leadership Processes across Cultures. Leadership Quarterly, 8, 233-274. https://doi.org/10.1016/S1048-9843(97)90003-5

Dubinina, I., \& Polinsky, M. (2013). Russian in the USA. In M. Moser (Ed.), Slavic Languages in Migration (pp. 1-29). University of Vienna Press.

European Institute for Gender Equality (2017). Gender Equality Index 2017: Poland.

Fisher, A., Jargova, K., Stenger, I., Avhustinova, T., Klakow, D., \& Mart, R. (2016). Orthographic and Morphological Correspondences between Related Slavic Languages as a Base for Modeling of Mutual Intelligibility. In N. Calzolari et al. (Eds.), Proceedings of the Tenth International Conference on Language Resources and Evaluation (LREC'16) (pp. 4202-4209). European Language Resources Association (ELRA).

Gerstein, M., Slobodskaya, H., Zylicz, P., Gosztyla, D., \& Nakagawa, A. (2010). A Cross-Cultural Evaluation of Temperament: Japan, USA, Poland and Russia. International Journal of Psychology and Psychological Therapy, 10, 55-75.

Glazunova, N. E. (2018). U.S.-Russian Relations: Dissonance of Ideologies. Journal of Global Initiatives: Policy, Pedagogy, Perspective, 12, 48-66.

Goel, A., \& Jo, M. (2012). International Anti-Bribery and Corruption Trends and Development (pp. 1-211). Ropes \& Gray.

Goraus, K., \& Tyrowicz, J. (2014). Gender Wage Gap in Poland, It Can Be Explained by Differences in Observable Characteristic? Working Paper No. 11 (128), Faculty of Economic Sciences, University of Warsaw.

Grosman, D. J. (2014). Language Development of Bilingual Russian/English Speaking Children Living in the United States: A Review of the Literature (Paper 365). Thesis, Southern Illinois University Carbondale.

Gunia, B., \& Brett, M. (2011). Paying a Price: Culture, Trust, and Negotiation Consequences. Journal of Applied Psychology, 96, 774-789. https://doi.org/10.1037/a0021986

Hale, H. (2011). The Myth of Mass Russian Support for Autocracy: The Public Opinion Foundations of a Hybrid Regime. Europe-Asia Studies, 63, 1357-1375. https://doi.org/10.1080/09668136.2011.601106

Hall, T., \& Hall, M. (1989). Understanding Cultural Differences: German, French, and Americans. Intercultural Press, Inc.

Henegan, J., Smith, C., \& Butler, S. (2019). Legal Systems in the United States. Westlaw Practical Law.

Hofstede, G. (1980a). Culture and Organizations: Software of the Mind. McGraw-Hill.

Hofstede, G. (1980b). Culture’s Consequences. Sage.

Hofstede, G. (2000). Culture's Consequences: Comparing Values, Behaviors, Institutions and Organizations across Nations. Sage. https://www.hofstede-insights.com

Hofstede, G. (2011). Dimensionalizing Cultures: The Hofstede Model in Context. Online Readings in Psychology and Culture, 2, Article 8.

https://doi.org/10.9707/2307-0919.1014

Kabzińska, I. (2011). Dialog Polsko-Rosyjski. Oszary Wspoldzialania, Nadzieje i Ograniczenia. Instytut Archeologii i Etnologii PAN, 55, 1-26.

Kagan, O., \& Dillon, K. (2010). Russian in the United States. In K. Potowski (Ed.). Lan- 
guage Diversity in the United States (pp. 179-194). CUP. https://doi.org/10.1017/CBO9780511779855.012

Kalikh, A. (2010). The Role of Civil Society in Fighting Corruption in Russia and Poland.

Kardas, A. (2011). Praktyczny wymiar dialogu w nauczaniu Fethullaha Gülena, W: Dialog chrześcijańsko-muzułmański. Historia $i$ współczesność, zagrożenia $i$ wyzwania, red. Magdalena Lewicka, Czesław Łapicz, 81-94.

Katz, L. (2007). Negotiating International Business-The Negotiator's Reference Guide in 50 Countries Around the World(2nd ed.). BookSurge.

King, C. P. (1990). A Linguistic and a Culture Competence: Can They Live Happily Together? Foreign Language Annals, 23, 65-70. https://doi.org/10.1111/j.1944-9720.1990.tb00341.x

Kohls, L. R. (1988). The Values Americans Live by. San Francisco State University.

Konarska, K. (2013). Z Kultura Im Do Twarzy-Oblicza polsko-rosyjkich Negocjacji. Colloquia Anthropologica Et Communicativa, 6, 263-273.

Konyushkevich, V., Rubashevskiy, K., \& Bazurin, G. (2019). Legal System in the Russian Federation, Overview. Liniya Prava Law Firm, Practical Law Westlaw.

Kooyers, J. (2015). The United States and Spain: A Comparison of Cultural Values and Behaviors and Their Implications for the Multi-Cultural Workplace. http://scholarworks.gvsu.edu/honorsprojects

Korzeniowski, K. (2014). Sociopolitical Mentality in Poland's Historical Regions. Przeglad Psychologiczny, 57, 51-67.

Kosuda, A. (2007). The Nature of Polish-Russian Relationships after the Year of 1989: The Legacy of the Past. Thesis, Iowa State University. https://lib.dr.iastate.edu/rtd/14852

Krzywda, J. (2017). Intercultural Negotiations in Supply Chains of the Example of Poland and Germany. Zeszyty Naukowe Politechniki Czestochowskiej, 2, 68-77. https://doi.org/10.17512/znpcz.2017.3.2.07

Lakomy, M. (2011). Główne problemy w stosunkach polsko-rosyjskich na poczatcu XXI wieku. In M. Stolarczyk (Ed.), Stosunki Polski z sasiadami w pierwszej dekadzie XXI (pp. 69-112). Wydawnictwo Uniwersytetu Ślaskiego.

Laroche, L., \& Morey, S. (2002). Career Catalyst Succeed in Business in Eastern Europe. Chemical Engineering Progress, 11, 84-98.

Lefebvre, V. A. (1982). Algebra of Conscience: A Comparative Analysis of Western and Soviet Ethical Systems. D. Reidel Publishing Company.

https://doi.org/10.1007/978-94-010-9051-3

Lewis, R. (2006). When Cultures Collide: Leading across Cultures (3rd ed.). Nicholas Brealey International.

Louneva, T. (2010). Business Negotiations between Americans and Russians. Wharton Research Scholars Journal, 57.

http://repository.upenn.edu/wharton_research_scholars/57

Lyons, T., \& Khadiagala, G. (2010). Conflict Management and African Politics: Ripeness, Bargaining and Mediation (1st ed.). Routledge. https://doi.org/10.4324/9780203930816

Lytle, A., Brett, J., Barsness, C., Tinsley, C., \& Janssens, M. (1995). A Paradigm for Confirmatory Cross-Cultural Research in Organizational Behavior. Research in Organizational Behavior, 17, 167-214.

Matsumoto, D., Yoo, S. H., \& Fontaine, J. (2008). Mapping Expressive Differences around the World: The Relationship between Emotional Display Rules and Individualism ver- 
sus Collectivism. Journal of Cross-Cultural Psychology, 39, 55-74. https://doi.org/10.1177/0022022107311854

Mazurkiewicz, L. (Ed.) (2015). Polska-Rosja Diagnoza Spoleczna 2015. Centrum Polsko-Rosjskiego Dialogu I Porozumienia. http://cprdip.pl/assets/media/Wydawnictwa/Raporty/POLSKA_ROSJA._Diagnoza_spo leczna_2015.pdf

Meerts, P. (Ed.) (2009). Negotiating with the Russian Bear: Lessons for the EU? EU Diplomacy Papers, Department of EU International Relations and Diplomacy Studies.

Meller, S. (2007). O stosunkach polsko-rosyjskich. Odczyt w stacji naukowej Polskiej Aka-demii Nauk w Paryzu. http://www.skubi.net/meller.html

Mendelsohn, M. (Ed.) (2015). The Anti-Bribery and Anti-Corruption Review (4th ed.). Law Business Research.

Mix, D. (2016). Poland and Its Relation with the United States (pp. 1-14). CRS Report, RS22163, Congressional Research Service.

Nishishiba, M., \& Ritchie, L. (2000). The Concept of Trustworthiness: A Cross-Cultural Comparison between Japanese and US Business People. Journal of Applied Communication Research, 28, 347-367. https://doi.org/10.1080/00909880009365581

Panarina, E. (2020). The Innovative Industrial Cluster Concept of Regional Management for Sustainable Development of Socioeconomic Systems. Problems of Management in the 21st Century, 15, 125-143. https://doi.org/10.33225/pmc/20.15.125

Potowski, K. (2010). Language Diversity in the United States: Dispelling Common Myths and Appreciating Advantages. In K. Potowski (Ed.). Language Diversity in the United States (pp. 1-24). CUP.

Public Opinion Research Center (2010). Polish Values: What Is Important, What Is Permitted, What Must Not Be Done. CBOS.

https://www.cbos.pl/PL/publikacje/public_opinion/2010/07_2010.pdf

Putnam, D. H., Oplinger, E. S., Hicks, D. R., Durgan, B. R., Noetzel, D. M., Meronuck, R. A., Doll, J. D., \& Schulte, E. E. (1990). Sunflower. In Alternative Field Crop Manual. University of Wisconsin-Exension, Cooperative Extension.

Qu, D. (2015). The Impact of Cultural Difference on International Business Negotiations. Academic Leadership Journal in Student Research, 3, Article 4.

Richardson, C., \& Rammal, H. (2018). Religious Belief and International Business Negotiations: Does Faith Influence Negotiator Behaviour? International Business Review, 27, 401-409. https://doi.org/10.1016/j.ibusrev.2017.09.007

Rimashevskaya, M. N. (2013). Gender Relationships and Gender Policy in Contemporary Conditions. Intelektiné Ekonomika Intellectual Economics, 7, 54-62.

Roemer, C., Garb, P., Neu, J., \& Graham, J. L. (1999). A Comparison of American and Russian Patterns of Behavior in Buyer-Seller Negotiations Using Observational Measures. International Negotiation, 4, 37-61. https://doi.org/10.1163/15718069920848363

Rose, D., Carausu, D., Crone, B., \& Sengupta, S. (2014). A Cross Cultural Examination of the United States and Russia Using Multiple Models. International Journal of Arts \& Sciences, 7, 459-470.

Rozkwitalska, M., Sulkowski, L., \& Magala, S. (2017). Intercultural Interactions in the Multicultural Workplace. Springer. https://doi.org/10.1007/978-3-319-39771-9

Schweitzer, M. E., \& Gomberg, E. L. (2001). The Impact of Alcohol on Negotiator Behavior: Experimental Evidence. Journal of Applied Social Psychology, 31, 2095-2126. https://doi.org/10.1111/j.1559-1816.2001.tb00165.x 
Schweitzer, M. E., \& Kerr, J. (2000). Bargaining Under the Influence: The Role of Alcohol in Negotiations. The Academy of Management Executive, 14, 47-57. https://doi.org/10.5465/ame.2000.3819305

Smirnova, O. (2013). Challenges of Business Negotiation Communications between Finnish and Eastern European Companies. Thesis, Turku University of Applied Sciences. http://urn.fi/URN:NBN:fi:amk-201302282769

Spector, B. (2008). Perverse Negotiations: Bribery, Bargaining and Ripeness. Conflict Management and African Politics. Routledge.

Tomi, L. (2001). Critical Analysis of American Representation of Russians. Pragmatics, 11, 263-283. https://doi.org/10.1075/prag.11.3.02tom

Toosi, N., Mor, S., Semnani, Z., \& Philips, W. K. (2018). Who Can Lean In? The Intersecting Role of Race and Gender in Negotiation. Psychology of Women Quarterly, 43, 7-21. https://doi.org/10.1177/0361684318800492

Transparency International (2019). Center for Anti-Corruption Research and Initiative Transparency.

Trompenaars, F., \& Hampden-Turner, C. (1997). Riding the Waves of Culture (2nd ed.). Nicholas Brealey.

Tu, Y.-T., \& Chih, H.-C. (2011). An Analysis on Negotiation Styles by Religious Beliefs. International Business Research, 4, 243-253. https://doi.org/10.5539/ibr.v4n3p243

U.S. Department of State (2019). U.S. Relation with Poland. https://www.state.gov/u-s-relations-with-poland/

U.S. Embassy \& Consulate in Poland (2020). Visa Waiver Program. https://pl.usembassy.gov/visas/visa-waiver-program

Uscilowicz, F. (2008). To Destroy Our Souls: Polish Perceptions on Russians between 966 to 1918 (pp. 1-51). Honors Papers, Rutgers Department of History.

Wach, A. (2016). L1-Based Strategies in Learning the Grammar of L2 English and L3 Russian by Polish Learners. System, 61, 65-74. https://doi.org/10.1016/j.system.2016.08.001

Warat, M. (2014). Development of Gender Equality in Poland. "A Review of Success and Limitation. Working Paper No. 2.2, Gender Equality Policy in Poland, Jagellonian University.

Wejnert, B., \& Djumabaeva, A. (2005). From Patriarchy to Egalitarianism: Parenting Roles in Democratizing Poland and Kyrgyzstan. Marriage \& Family Review, 36, 147-171. https://doi.org/10.1300/J002v36n03_08

Wilson, S. R., \& Drake, L. E. (2000). Culture in the Context of Intercultural Negotiation Human Communication Research, 26, 591-617. https://doi.org/10.1111/j.1468-2958.2000.tb00770.x

Witalisz, A. (2013). English Linguistic Influence on Standard and American Varieties of Polish: A Comparative Study. Studia Linguistica Universitatis Iagellonicae Cracoviensis, 130, 327-346.

Witaszek, Z. (2007). Kulturowe Uwarunkowania Negocjacji oraz Zasady Ich Prowadzenia. Zeszyty Naukowe Akademii Marynarki Wojennej, XLVIII, 101-119.

Wolska, B. (2001). History, Culture and Alcohol: Drinking Patterns in Poland and Australia. Thesis, Edith Cowan University. https://ro.ecu.edu.au/theses/1040

Wolski, T. (2016). Bariery w komunikacji Polaków i Rosjan-Stereotypy I różnice w kulturach biznesowych (pp. 1-6). Komunikacja Miedzynarodowa, University of Rzeszow. 